\title{
Adult education and the fostering of asylum seekers as "full" citizens
}

\author{
Andreas Fejes ${ }^{1}$ \\ Published online: 12 February 2019 \\ (C) The Author(s) 2019
}

\begin{abstract}
The role of adult education in the shaping and fostering of democratic citizens is prevalent in current transnational and national policy discussions; a significance which has been further infused by the past few years' historically high migration flows. This article focuses specifically on the role of adult education in shaping asylum seekers into "full" citizens in Sweden. Drawing on a poststructural discursive theorisation, the author analyses policy reports as well as interviews with project managers and leaders of study circles (a particular form of collaborative adult learning in Sweden) involved in a state-funded initiative called Svenska från dag ett [Swedish from Day One]. This programme emerged in the wake of the arrival of high numbers of asylum seekers in Sweden in the autumn of 2015 and onwards, providing them with an introduction to the Swedish language and to Swedish society. The author's analysis illustrates how a discourse on asylum seekers as "not yet citizens" emerges, where "they" still lack certain knowledge and capabilities deemed necessary to potentially become "full" citizens in Sweden. Such knowledge, besides language, concerns (Swedish) cultural and institutional (e.g. healthcare and taxation) knowledge. The article concludes by raising some questions regarding the way in which the need for country-specific language as a basis for inclusion is taken for granted.
\end{abstract}

Keywords adult education · study circles · asylum seekers · citizen formation · Sweden

\section{Résumé}

Éducation des adultes et transformation des demandeurs d'asile en citoyens « à part entière »-Le rôle de l'éducation des adultes dans la création et la stimulation et la promotion de citoyens démocratiques domine actuellement les débats stratégiques au niveau national et transnational. Cette prépondérance a été encore renforcée par les flux migratoires des dernières années qui ont atteint une ampleur historique. Le présent article traite de manière spécifique le rôle de l'éducation des adultes dans la transformation des demandeurs d'asile en citoyens suédois « à part entière ».

Extended author information available on the last page of the article 
S'inspirant d'une théorisation discursive post-structurale, l'auteur analyse des rapports stratégiques ainsi que des entretiens menés avec des directeurs de projets et animateurs de cercles d'études (une forme particulière de l'apprentissage collaboratif des adultes en Suède), impliqués dans une initiative publique baptisée Svenska från dag ett [Le suédois dès le premier jour]. Ce programme est apparu suite à l'arrivée de demandeurs d'asile en grands nombres en Suède à partir de l'automne 2015. Il leur propose une initiation à la langue et à la société suédoise. L'analyse de l'auteur illustre comment naît un débat sur les demandeurs d'asile qui ne sont « pas encore citoyens », car encore dépourvus de certaines connaissances et capacités jugées nécessaires pour devenir éventuellement citoyens suédois « à part entière ». Il s'agit, en plus de la langue, de connaissances d'ordre culturel et institutionnel (spécifiques à la Suède, par exemple systèmes fiscal et de santé). L'auteur conclut en soulevant plusieurs questions sur le fait que la nécessité de parler la langue du pays est considérée comme une base évidente de l'inclusion.

\section{Introduction}

Two key issues addressed in contemporary policy debates in Europe and beyond are (1) the role of adult education as a means of contributing to social change; and (2) how adult education as a learning space can shape democratic citizens. Both issues are reflected in UNESCO's most recent Recommendation on Adult Learning and Education $2015{ }^{1}$, which states:

The aim of adult learning and education is to equip people with the necessary capabilities to exercise and realize their rights and take control of their destinies. It promotes personal and professional development, thereby supporting more active engagement by adults with their societies, communities and environments. It fosters sustainable and inclusive economic growth and decent work prospects for individuals. It is therefore a crucial tool in alleviating poverty, improving health and well-being and contributing to sustainable learning societies (UNESCO 2016, p. 8).

This quotation demonstrates how adult learning and education (ALE) is proposed as a solution to a range of societal challenges ranging from the environment, to individuals becoming employed, to the more general aim of economic growth. This approach is mirrored in Sustainable Development Goal (SDG) 4 of the United Nations 2030 Agenda, which aims to "ensure inclusive and equitable quality education and promote lifelong learning opportunities for all" (UN 2015). These ambitions and prospects associated with adult education can also be seen in the policy-making

\footnotetext{
1 According to the Foreword, "The 2015 Recommendation on Adult Learning and Education (ALE) supersedes the 1976 Recommendation [on the Development of Adult Education] and is therefore the most up-to-date and comprehensive tool for ALE decision-makers, researchers, practitioners from governmental and civil society organizations, and other stakeholders around the globe" (UNESCO 2016, p. 3).
} 
of other transnational organisations, such as the European Union (EU). For example, the Council of the European Union, in its Resolution on a renewed European agenda for adult learning, states that:

The crisis has highlighted the major role which adult learning ${ }^{2}$ can play in achieving the Europe 2020 goals, by enabling adults - in particular the lowskilled and older workers - to improve their ability to adapt to changes in the labour market and society. Adult learning provides a means of up-skilling or reskilling those affected by unemployment, restructuring and career transitions, as well as makes [sic] an important contribution to social inclusion, active citizenship and personal development (CoEU 2011, p. 1).

The European agenda thus features a similar approach and similar expectations to those raised by UNESCO. The roles of adult education and learning are manifold, combining ideas about preparation for the labour market with active citizenship and personal development. As illustrated in the EU Resolution, there is a strong focus on the role of adult education as a means of adaptation, i.e. helping citizens "to adapt to" a constantly changing society. These ideas are similar to those represented in national-level policy-making, e.g. in Sweden, where formal (municipal) adult education is described as having at least three functions: a labour market function, a compensatory function [in terms of compensating for lack of previous educational opportunities or lack of support in previous education, ending up in an incomplete degree], and a democratic function (SFS 2010).

What these examples have in common, besides outlining specific roles of adult education, is that they entail certain normative assumptions concerning who the citizen should be - or rather become - in order to be included in and part of society. In other words, adults as such are deemed not yet citizens, despite being adults and thus already citizens in a formal sense. The issue is that the adult only becomes a citizen by engaging in adult education (see also Fejes et al. 2018a).

Even though adult learning and education addresses "all" citizens, the focus has often been directed towards those who are deemed to be at risk of exclusion, such as social security dependants single mothers, or migrants (see e.g. Fejes 2006; Sandberg et al. 2016). Lately, the policy focus has not least been directed towards the latter target group, migrants, in light of the past few years' migration flows and the historically high number of refugees coming to Sweden and other EU member states. A key question addressed by politicians has been: In what ways can newly arrived migrants be included as citizens in the new host society?

In Sweden, historically as well as currently (e.g. MoE 2015; Fejes et al. 2018a), much trust has been put into adult education as a means of supporting migrants on their path towards "full" citizenship. With a range of adult education institutions, migrants have been offered opportunities to engage in education in order to potentially be included in society as citizens. However, the recent migration flows have

\footnotetext{
${ }^{2}$ For the purposes of this text, the term adult learning covers the entire range of formal, non-formal and informal learning activities - both general and vocational - undertaken by adults after leaving initial education and training (CoEU 2011, p.1 [This footnote is part of the quotation.]).
} 
put great pressure on such state-funded institutions, and thus, the Swedish government has implemented a range of new initiatives particularly designed for asylum seekers. One such initiative has been Svenska från dag ett [Swedish from Day One], where study associations ${ }^{3}$ have been funded to provide asylum seekers with initial Swedish language knowledge as well as an introduction to Swedish society (Swedish Government 2017).

This article focuses on Swedish from Day One as one example of how Swedish adult education is used as a means for shaping migrants into "full" citizens, and investigates more precisely what such citizens should be like. This analysis provides a space for discussion on how the taken-for-grantedness of the present situation has the effect of excluding even as it strives to include. I begin by placing Swedish from Day One within the wider adult education context in Sweden, historically as well as currently. Next, I outline the theoretical and methodological positioning of the article. Third, I present the analysis before finally wrapping up the article with a concluding discussion.

\section{Adult and popular education in Sweden}

Sweden has a long history of institutionalised adult education, dating back to the mid-1800s and the emergence of popular education initiatives. Such initiatives included the appearance of folk high schools (the first school was created in 1868), ${ }^{4}$ study circles (the first circle was created in 1902), ${ }^{5}$ public libraries, distance education, public lectures and the creation of the first study association in 1912. The latter came into being in close cooperation between social movements (and their struggle for democracy) and the state (Larsson 2013; Gustavsson 2013). This close relationship has been retained throughout the 20th century and carried over into the 21st century, and can be seen as part of the corporatist Swedish welfare model (Micheletti 1995; Premfors 2000). In such a model, relations between the state and civil society organisations are construed as important for developing a more democratic society. The idea was that (political) decisions would thus be more embedded

\footnotetext{
${ }^{3}$ Study associations are affiliated with special interest groups such as a trade union, a political party, a church etc. Sweden currently has ten study associations, the oldest of which is Arbetarnas bildningsförbund (ABF [the Workers' Educational Association]), which was established in 1912. Study associations receive government grants, which are distributed by the Swedish National Council of Adult Education, and they run study circles (see separate explanatory footnote).

${ }^{4}$ Folk high schools originated in Denmark in the 1830s, where they were established as learning sites for peasants who wanted to become active citizens. For more information, see https://www.danishfolk highschools.com/about-folk-high-schools/history/ [accessed 18 January 2019]. Today, folk high schools, albeit differing slightly in terms of their concepts and traditions, are an integral part of non-formal adult learning not only in Scandinavia, but also in Germany, Austria and Switzerland.

5 Study circles are organised by study associations (see separate explanatory footnote). Though the study circle does have a leader, participants meet to learn collaboratively about a particular subject they are interested in. The range of subjects is infinite and includes languages, history, social and political issues, art, crafts, music etc. The circle leader is one of the group, and takes on the role as volunteer, i.e. it could be anyone. However, study associations do to some extent provide circles for their circle leaders in order to prepare them for their role.
} 
in broad layers of the population, while high levels of participation in the activities of study associations would contribute to the democratic fostering of the population (Dahlstedt 2009; Edquist 2009). Thus, popular education in Sweden is quite different compared to other locations where the relationship between popular education institutions (and initiatives) and the state is not close.

Today, the adult education system in Sweden (excluding higher education) is made up of, on the one hand, popular education institutions providing non-formal education, such as folk high schools and study associations, and on the other hand, formal adult education institutions such as higher vocational education and municipal adult education institutions, all of which are fully funded by public authorities (e.g. the state and/or municipalities or regional counties). Municipal adult education is the largest adult education provider in Sweden, serving almost as many students as the regular upper secondary school system does for young people. Within municipal adult education, adult students can study courses at compulsory (completion of lower secondary) and upper secondary level, and/or courses in Swedish for immigrants (see Fejes et al. 2018a for more details on the Swedish adult education system).

Compared to other countries' systems, the Swedish adult education system seems to be quite successful, at least in view of the Organisation for Economic Co-operation and Development (OECD)'s Programme for the International Assessment of Adult Competencies (PIAAC) study (Survey of Adult Skills), where Sweden scored top marks (OECD 2017, Figure 4.16), even though there are wide differences between individuals with high skills and those with low skills in Sweden (Statistics Sweden 2013). Among those with low skills, we find poorly educated people and migrants. However, a relatively recent study indicates that adult education in Sweden does have positive effects for migrants, especially those born outside the Nordic countries (Nordlund et al. 2013). Among the effects identified were improved long-term labour prospects, positive income development, and individuals' enablement to embark on educational trajectories. Similar conclusions can be drawn from a slightly earlier study which focused on analysing the effects of participation in Swedish language courses for immigrants (Kennerberg and Åslund 2010). Ten years after completing their course, migrants who took part in the Swedish for Immigrants programme (Svenska för invandrare; SFI) had a slightly higher rate of employment compared to those who did not participate in SFI.

\section{Study associations and Swedish from Day One}

This article gives particular attention to study associations. As outlined above, in Sweden, the state and popular education institutions are closely connected. The state provides basic funding to study associations (and folk high schools), enabling these institutions to provide courses and study circles of their own design, in terms of content as well as pedagogical form. Participation in these popular adult education activities is "free and voluntary". However, at least in relation to activities conducted using state funding, study associations (and folk high schools) do need to follow the state's aims for popular education. In Swedish constitutional law, these aims are 
broadly defined in terms of giving "everyone the opportunity, together with others, to increase their knowledge and 'Bildung' for personal development and participation in society" (SFS 2015, p. 218). ${ }^{6}$ Popular education should also, according to the state's aims, support activities that contribute to the strengthening and development of democracy, increase people's influence on their life situation, create engagement to participate in the development of society, and close the educational gaps between individuals and groups in society.

The basic funding for popular education is distributed through the Swedish National Council of Adult Education (Folkbildningsrådet), a non-profit association with certain authoritative tasks delegated by the government. The council also conducts quality audits in order to report back to the government. Members of the council are the organisations representing the study associations (and the folk high schools). ${ }^{7}$ Besides basic funding through state grants, study associations (and folk high schools) also attract other means of revenue. One source of income is engagement in tasks commissioned by the state, municipalities or state agencies. Among these commissioned tasks is Swedish from Day One, which this article focuses on. In autumn 2015, the Swedish government, facing the largest migration flows since the Second World War, made funding available for study associations (and to some extent folk high schools) in order to set up study circles for asylum seekers providing an introduction to the Swedish language and society. Between autumn 2015 and the end of 2017, more than 120000 unique participants (asylum seekers) had participated in these activities, which makes up more than half of all asylum seekers coming to Sweden during this period (Swedish Government 2017; Fejes et al. 2018b; Fejes and Dahlstedt 2017).

\section{Theorisation and method}

In order to gain an understanding of how citizens are shaped and fostered through adult education, more particularly through Swedish from Day One, I mainly draw on a theorisation inspired by the work of French philosopher and social theorist Michel Foucault, and by education scholars who have developed his ideas (Foucault 1972, 1980, 1998; Fejes 2005, 2006, 2010; Nicoll et al. 2013; Olson et al. 2015; Simons and Masschelein 2008). Of central concern are such concepts as discourse, power and subjectivity.

To begin with, "discourse" includes what is said through speech or writing (Foucault 1972). A statement concerning citizenship then refers to what is being said about citizenship within a specific discourse, and what can be taken

\footnotetext{
${ }^{6}$ My own translation for the purposes of this article. I chose to render the Swedish term bildning with the German term Bildung here, because translating it into "education" is too narrow. Bildung (preferred by several scholars writing in English) refers to personal formation and growth through understanding, learning and acquiring knowledge, becoming cultivated in the process.

7 For more information (in English), visit http://www.folkbildningsradet.se/om-folkbildningsradet/Overs attningar/English-translations/ [accessed 21 January 2019].
} 
seriously in terms of the statement's conformity with the "rules" of this discourse (Nicoll et al. 2013).

Through discourses of citizenship, power operates and shapes the possible field of action. In this context, power is conceptualised as being relational and non-intentional. Rather than asking the question of "Where is power?" and "Where does it come from?", Foucault (1998) suggests that we should ask the "how" questions of power: How is power exercised? What are the means by which it is exercised? What happens through this exercise of power? What are the effects of this power? With such a perspective, power is understood as operating everywhere, in all relations (Foucault 1998), and it only exists through actions, such as in the way that actions modify other actions within the relationships of groups or individuals. Power makes certain actions and distinctions possible.

Through power relations, subjectivity emerges. Power defines who can speak, about what and with what authority. Thus, a discourse makes available a certain field of possible subject positions to take up, including the positions of teacher, student, citizen and other positions. Thus, subjectivity is neither predefined, nor does it have any essence. Rather, subjectivity (in this case, the citizen) emerges through discourse, i.e. through the way citizens are spoken about. In other words, this is a decentred notion of subjectivity, and it is enmeshed in power relations, which makes these subjectivities possible (Foucault 1998; Fejes and Nicoll 2015). In line with this perspective, it is crucial to further analyse discourses defining how citizens should appear, behave and think in order to be "good citizens". In the ongoing formation of citizens as particular kinds of subjects, citizen-subjects are formed in a continuum between the normal (i.e. the ideal citizen) and the deviant others (i.e. those lacking the virtues and competences ascribed to the ideal citizen). Therefore, the formation of citizens is a question of the drawing of boundaries, making inclusion and exclusion possible.

In sum, my discursive theorisation directs attention towards the ways citizens are shaped and fostered through current discourses on citizenship and the role assigned to adult education in such fostering. Through such discourses, some citizens are shaped as desirable, having certain skills and capabilities, while others are construed as abnormal and in need of behavioural modification in order to be included in society as "good", well-adapted citizens. In other words, the focus in the kind of analysis I am presenting here is directed towards the selfevidence of current practices in order to provide a space for critique (see e.g. Foucault 1983; Fejes and Dahlstedt 2013). This does not mean, however, that my aim is to provide another universal truth or meta-narrative of the present or to define what is good or bad; rather, my aim is to offer critique. Or, as Foucault argues:

My point is not that everything is bad, but that everything is dangerous, which is not exactly the same as bad. If everything is dangerous, then we always have something to do. So my position leads not to apathy but to a hyper- and pessimistic activism (Foucault 1983, pp. 231-32). 


\section{Empirical material}

This article draws on an ongoing research project I am directing, the purpose of which is to analyse the ways asylum seekers are shaped and fostered as citizens. The project focused on Swedish from Day One, a programme organised by the Workers' Educational Association (Arbetarnas bildningsförbund; ABF), the largest study association in Sweden. Based at Linköping University, our team selected three locations (municipalities) in Sweden where ABF organised study circles in Swedish from Day One. In order to provide variety for our sample, we chose activities organised in one large municipality, one medium-sized city and one rural municipality. In each location, we interviewed asylum seekers participating in the study circles, study circle leaders and project managers responsible for the activities. The interviews were evenly distributed across the locations and in total we interviewed 46 ( 21 female, 25 male) asylum seekers, 8 ( 4 female, 4 male) study circle leaders and 9 ( 3 female, 6 male) project managers. Observations of the activities were also conducted at each location. Furthermore, the project included collecting text material such as governmental reports on the initiative, reports from the National Agency for Adult Education which distributes the state funding for these study circles, and reports from those organisations involved in the activities (for more details on the project, see Fejes et al. 2018b).

Our interviews with participant asylum seekers focused on their view on what they were doing in the circles, what they thought of the quality, their background in terms of country of origin, their current social networks, their prior education and labour market experience, and their ideas and aspirations for the future. Even though many of the participants had only been in Sweden for a relatively short time, their Swedish was deemed to be of such quality that it was possible to carry out the interviews as described above. In some cases, however, interviews were conducted with an interpreter, and in some interviews, we resorted to English. Interviews with study circle leaders and project managers focused more on the specific activities of Swedish from Day One, the rationale, content, planning and reflections on their participants' progress and future (in a general sense, not regarding specific individuals). All interviews were transcribed verbatim. The study was conducted according to ethical guidelines in terms of voluntary participation, anonymity, and the right to withdraw from the study. The project has undergone formal ethical vetting and it has been approved by the regional ethical committee.

The interview data were, in a first round, thematically analysed in terms of what was assigned importance in terms of background, the study circles, and the future. Second, we identified regularities and irregularities in the descriptions of these themes. What became clear, not surprisingly, in the interviews with study circle leaders and project managers, was on the one hand that these interviews were more developed compared to interviews with participants (due to language skills), and on the other hand that it was in these interviews that norms about what a Swedish citizen is and should be were most prevalent. For the purposes of this article, I confine the interview material I draw on for my analysis to the interviews with study circle leaders and project managers, totalling 17 interviews. 
However, norms about what a Swedish citizen "is" and should be are also prevalent in the textual material, which I also include as a basis for the analysis I am presenting here. More precisely, the textual material consists of four policy texts and reports that concern Swedish from Day One: (1) the government budget for 2018 (Swedish Government 2017); (2) a report by the Swedish National Council of Adult Education (2017); (3) a report produced by the lobby organisation for all ten study associations in Sweden (Swedish Adult Education Association 2016); and (4) a report produced by ABF (2017).

In the following sections, I present the analysis. First, I identify the policy discourse as it is shaped through the four reports; this is followed by an analysis of the ways in which such a discourse is picked up and mobilised by study circle leaders and project managers. Next, I focus on what knowledge in particular is construed as being necessary in order to become a "full" citizen, and finally, I discuss how Swedish from Day One emerges as a fostering activity.

\section{Policy discourse}

There are common factors across the four reports in terms of shaping Swedish from Day One as a key intervention necessary to include migrants in the labour market as well as society more widely. With increasing migration to Sweden, it is argued that there is a need to find new ways to provide relevant day-to-day activities for asylum seekers. By learning Swedish and gaining knowledge about Swedish society, the idea is that migrants will become better prepared for participation in the labour market and in society, and have better chances of becoming "full" citizens in the future. This line of reasoning is visible in the following quotation from the Swedish Minister for Adult Education, when elaborating on Swedish from Day One:

Today, a large number of people are coming to Sweden, from war and oppression. It is important for us to work together to make their initial time in Sweden as good as possible in order to make their inclusion in society and the labour market easier. The Swedish language is the most important tool for inclusion. Thus, the Government has launched the initiative "Swedish from Day One" whereby asylum seekers and newly arrived migrants living in refugee accommodation can strengthen their skills in the Swedish language and knowledge about Swedish society (Swedish Adult Education Association 2016, p. 11). ${ }^{8}$

Here, "the Swedish language" and "knowledge about Swedish society" are positioned as the most important tools for migrants in order to be included in the labour market and society more widely. Similar notions emerge in the government budget for 2018:

Popular education is an important factor within the Government strategy concerning early interventions for asylum seekers ... Early interventions are

\footnotetext{
${ }^{8}$ For the purposes of this article, I have translated all quotations from Swedish sources into English.
} 
important in order to use the asylum-seeking time in a good way and in order to make a future establishment easier for those who receive a residence permit ... Swedish from Day One has been successful, and more than 120000 individual participants have acquired basic language skills and knowledge about Swedish society through participation in popular education (Swedish Government 2017, p. 50).

Here, knowledge of the Swedish language as well as about Swedish society once again emerges as important. However, such notions are complemented by the idea of "early interventions", which are expected to make a future establishment easier (for those who are granted a residence permit). The initiative is also construed as being highly successful, reaching a large number of asylum seekers, i.e. the target group the programme was designed for. A similar way of speaking about Swedish from Day One emerges when focusing on the report from the Swedish National Council of Adult Education, where it is argued that Swedish from Day One aims to "strengthen knowledge of the Swedish language" as well as knowledge "about Swedish society" (Swedish National Council of Adult Education 2017, p. 51). Such knowledge is expected to make the transition into the labour market, and society more widely, easier.

Turning to the report from $\mathrm{ABF}$, the reasons for their working with asylum seekers are described in the following way:

ABF should educate about the history and foundation of the asylum process in Sweden ... ABF should, in our present time, take advantage of people's solidarity and engagement for asylum seekers ... Language and work are two important key factors for integration ... ABF creates meeting places where people with different backgrounds are provided with the opportunity for new meetings where knowledge and culture are at the centre. (ABF 2017, p. 1)

Here, notions such as "solidarity", "engagement", "knowledge" and "culture" are highlighted as being important. The focus is very much on drawing on local citizens' solidarity and engagement for people who are in a tough situation. Contentwise, culture is construed to be of key importance, where ABF can act as a mediator for people to meet across cultures, at the same time as providing opportunities to learn the Swedish language.

Together, the four reports shape a discourse that construes asylum seekers as being in need of early interventions in terms of learning the Swedish language as well as gaining knowledge about Swedish society. Such learning should emerge by drawing on local citizens' solidarity and engagement, and thus spaces where people can meet across cultures emerge.

\section{Picking up and mobilising policy discourse}

Turning to our interviews with study circle leaders and project managers, what emerges are similar notions to those discernible in reports and policy texts of what Swedish from Day One should be about. In our interviewees' responses, Swedish from Day One is construed as involving helping asylum seekers to learn 
the Swedish language as well as providing information about Swedish society. However, these two knowledge areas are described as intermingling, as expressed by one of the project managers:

"Civic education together with Swedish language learning is the basis. We sneak civic education teaching into the language learning ... We try to inform about society and carry out field trips when the students understand a bit more" (Project manager 7).

Civic education, or rather knowledge about Swedish society, is construed here as something that is surreptitiously "snuck" into the language learning teaching rather than being taught as a separate subject. As described by several of the project managers and study circle leaders, this is done by, for example, drawing on current affairs in society as a basis for discussions, or by using newspapers in their teaching. In this way, civic education is construed as an introduction to, and information about, Swedish society rather than regular civic education. As expressed by another project manager:

"People do not want to sit here and study civic education when they know that they will engage in this in the next phase [for those who get a residence permit]. So, we wish to provide this information about Sweden ... Life here is different from life in their home countries. Many things operate differently here. They are not used to the democratic values here [in Sweden]. It's good to receive this information as soon as one arrives rather than later" (Project manager 1).

More regular civic education studies are offered during the next phase of becoming established in Swedish society, and then only for those who have obtained a residence permit. The asylum seeker is thereby on the one hand shaped as a potential Swedish citizen, i.e. someone who might potentially receive a residence permit. He or she is shaped as lacking something which needs to be provided in order to start on his or her path towards becoming a "full" citizen. Or rather, the asylum seeker is construed as a potential Swedish citizen in the making. On the other hand, asylum seekers are shaped as different compared to Swedes in terms of democratic schooling and values. Thus, information about Swedish society, as early on in the asylum process as possible, is seen to be necessary. Information about Swedish society also includes learning about one's rights and duties as a citizen:

"You can receive a lot of information and much more if you get the chance to find out about your rights and duties early on when arriving in Sweden. This, I believe, is crucial. During the asylum process you are mentally challenged. Thus, it is hard to motivate asylum seekers who have been here a while to get going with their studies" (Project manager 1).

Notions about rights and duties are introduced here as crucial for asylum seekers to learn as early on as possible, otherwise there is a risk that their mental capacity will limit what can be learned. All in all, civic education, or rather knowledge 
about Sweden, emerges as being considered crucial for asylum seekers on their path towards potential inclusion in Swedish society. The question then is, what specific knowledge about Swedish society is deemed necessary for them to learn?

\section{Knowledge contents}

In our interview transcripts, three main areas of knowledge emerge as being important for asylum seekers to learn about in order to be included in Swedish society: language, cultural knowledge and institutional knowledge.

\section{Language}

Knowledge about the Swedish language is seen as important, not only for the sake of language knowledge in itself, but rather as a basic key which unlocks access to learning other skills necessary to be included in Swedish society. This may be in order to gain employment, or in order to engage with people in life more generally. As one of the study circle leaders expressesed it:

"I used to tell the participants that the basis for living in a country is language and communication. If you can't communicate, it will be difficult to be included in society. This is about integration, about everything, you cannot do anything without communication" (Study circle leader 1).

Despite communication being a central concept in the above statement, the focus of these study circles, as emerges from the interview transcripts, is very much on knowledge of the Swedish language. Asylum seekers do of course have language skills, but here such skills emerge as the wrong ones. Or rather, asylum seekers are construed as lacking something, in this case knowledge of the Swedish language, which they need to develop in order to be included in the new social space in which they now find themselves. A project manager indicates the central role of learning the Swedish language in terms of being a tool for further development and inclusion.

"I believe they [these study circles] have several functions. The first is of course the role of providing tools. Language is a tool. So that you can communicate. This is of great importance" (Project manager 3).

\section{Cultural knowledge}

In our analysis of the reports, culture emerged as important, not least in terms of creating spaces to learn across cultures. Similar notions were mobilised in the interviews. As expressed by one of the study circle leaders:

"I check with the groups to see what they want. We do fun things. For example, we have a culinary buffet a couple of times each semester. Everyone brings something that's specific to their country. For me it might be that I bring a sandwich cake. That's pretty Swedish" (Study circle leader 7). 
In this response, food emerges as a specific marker for different cultures. Participants are asked to define what is typical for their culture, and display this to the others. Through such statements, an essentialised notion of culture is mobilised, where possibilities emerge to define what belongs and what does not belong to a specific culture. In doing so, it becomes possible to speak about Swedish culture as something different compared to other cultures, which is illustrated in the following quotation from the same study circle leader:

"I teach a lot about traditions, why we celebrate the way we do, why we have a Christmas star, what will happen during the coming days. They learn such things all the time, at least from me" (Study circle leader 7).

In this statement, on the one hand, traditions emerge as culturally bound, exemplified here by Christmas and the Christmas star. Thus, knowledge of different cultures is not only shaped as important, but rather knowledge of Swedish culture in itself emerges as essential to being included in society. However, the transcripts also feature some irregularities regarding such notions. For example, when discussing teachers working in the Swedish for Immigrants programme (SFI), which is part of the formal adult education system, another study circle leader says:

"Those [teachers] who are not qualified. They come here and disseminate, they come to the classroom and only distribute some facts about summer, midsummer, Christmas food and so on. Do you see what I mean? Such trifles" (Study circle leader 8).

Here, specific traditional practices are construed as trifles, as unimportant and not something one should really engage with in teaching. Such statements open up possibilities to speak about content in learning about Swedish society as something other than teaching about traditions.

\section{Institutional knowledge}

Institutional knowledge is a third knowledge area emerging from our interview transcripts as being of high importance for asylum seekers to acquire in order to potentially become "full" citizens. This includes knowledge about the taxation system, for example, or knowledge about how to get a job in Sweden. As expressed by one of the study circle leaders, there is a need to teach about how

"society functions, queuing for medical care, about tax and such things. We discuss this all the time" (Study circle leader 7),

or, as expressed by another study circle leader:

"You might explain a bit about society based on your own experience. We do not limit ourselves to teaching them the Swedish language, but also about society. It could be about health or anything they have questions about. It could be about the labour market" (Study circle leader 6). 
In order to provide such institutional knowledge, study circle leaders not only draw on their own experience, but they also invite representatives from different welfare institutions to the study circles. This might be someone from the hospital, the police or the job centre. As expressed by one of the study circle leaders:

"We handle some of the topics ourselves, and for some topics we borrow lecturers from the hospital or the police and so on. They come here and give a lecture. And we might act as interpreters. But some of the content regarding civic education teaching is delivered by us" (Study circle leader 8 ).

Although institutional knowledge emerges as important for asylum seekers on their path towards potential inclusion as "full" citizens, such knowledge is also construed as important for them in their role as asylum seekers. Asylum seekers might have children who go to school, or they might need medical care etc., and thus they need knowledge to navigate the Swedish welfare system. As expressed by one of the study circle leaders:

"It's better for them to learn how to book a doctor's appointment, have a meeting with their children's teachers, or participate in [their children's] school appraisals" (Study circle leader 3).

In sum, institutional knowledge emerges as key in terms of shaping future "full" citizens.

\section{Fostering responsible citizens}

Besides notions of what kind of knowledge is deemed necessary in order to become a "full" citizen, what also emerges from our interview transcripts are notions of fostering asylum seekers. Such fostering concerns the shaping of responsible and respectful future citizens. This is alluded to in the following quotation from one of the study circle leaders:

"Here, we have to help each other and get organised. That's how I was raised. And then, there are a lot of people, when they drink coffee. They don't clean their coffee mugs. So, no, we have to, you have to wash [your coffee mug]. That's what's called fostering, what [the fostering] we'll do for them ..." (Study circle leader 5).

Here, ideas about taking responsibility, or lack thereof, as well as the idea of fostering (i.e. demonstrating local customs and practices), emerge. Normative claims concern the need for people to take responsibility for themselves, and thus contribute to the wider good, or rather, the collective order of things. The fostering aspect continues to emerge in the same interview when the study circle leader takes an example from his teaching. As private property is viewed differently in different countries, he illustrates this for the participants during walks in the local neighbourhood.

"One thing they don't understand, when there is a house with a garden lacking a fence, they think its public ... 'There are apples [in the garden] and I'm hun- 
gry.' 'No, you knock on the door and ask if you can take some apples. If they agree, you can take some, otherwise you have to leave.' This is about fostering" (Study circle leader 5).

Here, an idea emerges that spatiality to property is signalled differently in different countries, and this is something asylum seekers need to learn. Or rather, they need to learn about how private and public property in Sweden is viewed. Asylum seekers are thus positioned as lacking the correct knowledge about how things are in Sweden, and the circle leader construes himself in a fostering role. In sum, what emerges is a discourse on a responsible citizen, who takes responsibility for himself or herself as well as learning and following the social moral order of things.

\section{Concluding discussion}

The focus of this article has been on how asylum seekers are shaped and fostered into "full" citizens through adult education. Drawing on a discursive approach analysing interviews with study circle leaders and project managers engaged in Swedish from Day One, as well as policy texts and reports on the topic, I have illustrated how asylum seekers are construed as lacking something, and as being in need of further work and development. Despite already having certain knowledge and capacities, language-wise as well as otherwise, asylum seekers are construed as needing knowledge about the Swedish language. The Swedish language emerges as a basis in order to access practices and to gain opportunities to develop the knowledge needed in order to be included as "full" citizens. Here, knowledge about Swedish society is construed as being of special importance. Such knowledge includes learning about Swedish traditions, as well as learning about Swedish institutional systems, e.g. medical care and taxation. Further, notions of morals emerge where citizens learn to take responsibility for themselves as well as learning about the wider moral order of things.

This analysis raises several potential points for further discussion, a few of which I focus upon here. First, the necessity of learning the language of the new potential country of residence has in previous research been indicated to be a mainstream discourse in relation to migration, as a basis for being included in society, not least in order to get a job (see e.g. Andersson and Fejes 2010; Andersson and Osman 2008; Gibb 2015). However, one of the effects of such a notion of the need to know the Swedish language is exclusion. By positioning the Swedish language as the most fundamental knowledge needed for inclusion, other language skills are marginalised, at the same time as the space for thinking more broadly becomes limited. One might ask whether it is really necessary to learn the Swedish language in order to get a job, or rather, if so, what is desired? This points to the rather intricate issue of how ideas become so self-evident that other ways of thinking and acting become hard or almost unthinkable.

Second, the very focus on culture and ideas of certain specific Swedish norms and traditions contributes to homogenising the Swedish social space. Sweden's population, like that of many other countries, includes a high proportion of migrants 
(first, second or third generation), and thus what could be termed "Swedish traditions" is constantly changing. Or rather, there are a range of traditions practised in Sweden, and thus defining and presenting things labelled as "Swedish traditions" in specific limited ways excludes as it includes. Thus, the question could be raised as to whether adult education should be mobilised as a tool for shaping asylum seekers (or, for that matter, any other learner) into previously constructed depictions of what is desirable according to dominating discourses.

By proposing a critical reading such as the one presented in this article, I do not propose to abolish the ambition to support asylum seekers in learning Swedish, nor to abolish the ambition to teach asylum seekers about Swedish society. However, I propose that all of us who engage in these kinds of activities and discussions need to be careful and critical towards the way we speak and go about doing these things, as our conceptualisation has effects in terms of shaping citizen subjectivity. The same caution applies to transnational organisations such as UNESCO, and the kind of policy discourse they shape and promote. By outlining adult learning, as illustrated in the introduction to this article, as the solution to (almost all) challenges society is said to face today, certain kinds of subjectivities emerge as desirable, which in turn exclude at the same time as they include. The exclusion-inclusion dichotomy is the effect of the exercise of power, and since power is dangerous and operates everywhere there is, as Foucault (1983, pp. 231-232) argues, always "something to do".

Acknowledgements This article is partly based on data generated within a research project on Swedish from Day One. I would like to acknowledge the contribution to this project made by professor Magnus Dahlstedt, associate professor Sofia Nyström and lecturer Nedžad Mešić. The article was supported by Linköping University as well as by a research grant from ABF (Arbetarnas bildningsförbund, the Swedish Workers' Educational Association).

Open Access This article is distributed under the terms of the Creative Commons Attribution 4.0 International License (http://creativecommons.org/licenses/by/4.0/), which permits unrestricted use, distribution, and reproduction in any medium, provided you give appropriate credit to the original author(s) and the source, provide a link to the Creative Commons license, and indicate if changes were made.

\section{References}

ABF (Arbetarnas bildningsförbund [Workers' Educational Association]). (2017). ABF - Årsrapport till Folkbildningsrådet angående asylverksamhet 2016 [Annual report to the Swedish National Council of Adult Education regarding asylum activities 2016]. Stockholm: ABF.

Andersson, P., \& Osman, A. (2008). Recognition of prior learning as a practice for differential inclusion and exclusion of immigrants in Sweden. Adult Education Quarterly, 59(1), 42-60.

Andersson, P., \& Fejes, A. (2010). Mobility of knowledge as a recognition challenge: Experiences from Sweden. International Journal of Lifelong Education, 29(2), 201-218.

CoEU (Council of the European Union). (2011). Council resolution on a renewed agenda for lifelong learning. Official Journal of the European Union, C372, 20 December. Retrieved 17 January 2019 from https://eur-lex.europa.eu/legal-content/EN/TXT/PDF/?uri=CELEX:32011G1220 (01)\&from $=\mathrm{EN}$.

Dahlstedt, M. (2009). Aktiveringens politik: Demokrati och medborgarskap för ett nytt millennium [The politics of activation: Democracy and citizenship for a new millennium]. Malmö: Liber.

Edquist, S. (2009). En folklig historia [A popular history]. Umeå: Boréa. 
Fejes, A. (2005). New wine in old skins: Changing patterns in the governing of the adult learner in Sweden. International Journal of Lifelong Education, 24(1), 71-86.

Fejes, A. (2006). The Planetspeak discourse of lifelong learning in Sweden: What is an educable adult? Journal of Education Policy, 21(6), 697-716.

Fejes, A. (2010). Discourses on employability: Constituting the responsible citizen. Studies in Continuing Education, 32(2), 89-102.

Fejes, A., \& Dahlstedt, M. (2013). The confessing society: Foucault, confession and practices of lifelong learning. London: Routledge.

Fejes, A., \& Dahlstedt, M. (2017). Popular education, migration and a discourse on inclusion. Studies in the Education of Adults, 49(2), 214-227.

Fejes, A., Dahlstedt, M., Olson, M., \& Sandberg, F. (2018a). Adult education and the formation of citizens: A critical interrogation. London: Routledge.

Fejes, A., Dahlstedt, M., Mesic, N., \& Nyström, S. (2018b). Svenska(r) från dag ett: En studie av ABFs verksamhet med asylsökande [Swedish/Swedes from Day One: A study of ABF's activities with asylum seekers]. Stockholm: Arbetarnas bildningsförbund (ABF).

Fejes, A., \& Nicoll, K. (Eds.). (2015). Foucault and a politics of confession in education. London: Routledge.

Foucault, M. (1972). The archaeology of knowledge. New York: Harper.

Foucault, M. (1980). Power/knowledge, selected interviews and other writings 1972-1977. Brighton: Harvester Press.

Foucault, M. (1983). On the genealogy of ethics: An overview of work in progress. In H. L. Dreyfus \& P. Rabinow (Eds.), Michel Foucault: Beyond structuralism and hermeneutics (pp. 229-251). Chicago, IL: The University of Chicago Press.

Foucault M. (1998). The will to knowledge. The history of sexuality, vol. 1. London: Penguin.

Gibb, T. (2015). Regimes of language skill and competency assessment in an age of migration: The in/ visibility of social relations and practices. Studies in Continuing Education, 37(3), 228-267.

Gustavsson, B. (2013). The idea of democratic Bildung: Its transformations in time and space. In A.-M. Laginder, H. Nordvall, \& J. Crowther (Eds.), Popular education, power and democracy: Swedish experiences and contributions (pp. 35-49). Leicester: National Institute of Adult Continuing Education (NIACE).

Kennerberg, L., \& Åslund, O. (2010). SFI och arbetsmarknaden [Swedish for Immigrants (SFI) and the labour market]. Uppsala: Institutet för arbetsmarknads- och utbildningspolitisk utvärdering (IFAU).

Larsson, S. (2013). Folk high schools as educational avant-gardes in Sweden. In A.-M. Laginder, H. Nordvall, \& J. Crowther (Eds.), Popular education, power and democracy: Swedish experiences and contributions (pp. 72-96). Leicester: National Institute of Adult Continuing Education (NIACE).

Micheletti, M. (1995). Civil society and state relations in Sweden. Aldershot: Avebury.

MoE (Ministry of Education). (2015). Ökad individanpassning: en effektivare SFI och vuxenutbildning [Increased personalization: A more efficient Swedish for Immigrants (SFI) and adult education]. Stockholm: Ministry of Education.

Nicoll, K., Fejes, A., Olson, M., Dahlstedt, M., \& Biesta, G. (2013). Opening discourses of citizenship education: A theorization with Foucault. Journal of Education Policy, 28(6), 828-846.

Nordlund, M., Bonfanti, S., \& Strandh, M. (2013). Second chance education matters! Income trajectories of poorly educated non-Nordics in Sweden. Journal of Education and Work, 28(5), 528-550.

OECD (Organisation for Economic Co-operation and Development). (2017). OECD Skills outlook 2017: Skills and global value chains. Paris: OECD Publishing. Retrieved 21 January 2019 from https:// www.oecd-ilibrary.org/docserver/9789264273351-en.pdf?expires $=1548076208 \& i d=i d \& a c c n a$ me $=$ ocid195767\& checksum =8D81C271C5363ACDCCB98486E8C75285.

Olson, M., Fejes, A., Dahlstedt, M., \& Nicoll, K. (2015). Citizenship discourses: Production and curriculum. British Journal of Sociology of Education, 36(7), 1036-1053.

Premfors, R. (2000). Den starka demokratin [The strong democracy]. Stockholm: Atlas.

Sandberg, F., Fejes, A., Dahlstedt, M., \& Olson, M. (2016). Adult education as a heterotopia of deviation: A dwelling for the abnormal citizen. Adult Education Quarterly, 66(2), 103-119.

SFS (Svensk författningssamling [Swedish Code of Statutes]). (2010). SFS 2010:800 Svensk författningssamling: Skollagen [Swedish code of statutes SFS 2010:800: The school law]. Stockholm: Ministry of Education.

SFS. (2015). SFS 2015:218. Svensk författningssamling. Förordning om statsbidrag till folkbildningen [Swedish code of statutes SFS 2015:218: Law concerning state funding for popular education]. Stockholm: Swedish Government. 
Simons, M., \& Masschelein, J. (2008). The governmentalization of learning and the assemblage of a learning apparatus. Educational Theory, 54(4), 391-415.

Statistics Sweden. (2013). Den internationella undersökningen av vuxnas färdigheter [The international study of adult skills]. Örebro: Statistiska centralbyrån (SCB).

Swedish adult education association. (2016). Svenska från dag 1: En dokumentation av de tio studieförbundens verksamhet med asylsökande och på asylboenden [Swedish from Day One: A documentation of the ten study associations' activities with asylum seekers and asylum residents]. Stockholm: Swedish adult education association.

Swedish Government. (2017). Prop. 2017/18:1. Government budget 2018. Expenditure area 17, Culture, media, religious community and leisure time. Stockholm: Swedish Government.

Swedish National Council of Adult Education. (2017). Folkbildning med asylsökande 2016: Svenska från dag ett och vardagssvenska i studieförbund och folkhögksolor [Popular education with asylum seekers 2016: Swedish from Day One and everyday Swedish in study associations and folk high schools]. Stockholm: Folkbildningsrådet (Swedish National Council of Adult Education).

UN (United Nations). (2015). Transforming our world: The 2030 Agenda for Sustainable Development. A/RES/70/1. New York: UN. Retrieved 23 January 2019 from https://sustainabledevelopment.un. org/post2015/transformingourworld.

UNESCO (United Nations Educational Scientific and Cultural Organization). (2016). Recommendation on adult learning and education 2015. Paris/Hamburg: UNESCO/UNESCO Institute for Lifelong Learning. Retrieved 11 January 2019 from https://unesdoc.unesco.org/ark:/48223/pf0000245179.

Publisher's Note Springer Nature remains neutral with regard to jurisdictional claims in published maps and institutional affiliations.

Andreas Fejes is professor and chair of adult education research at Linköping University in Sweden where he directs one of the larger research groups on adult education in the world (30 researchers and university teachers). His research interests currently concern issues of migration, learning and citizenship; consequences of the marketisation of adult education; as well as issues about how the research field of adult education and learning is shaped (through bibliometrical studies). He is one of the founding editors of the European Journal for Research on the Education and Learning of Adults.

\section{Affiliations}

\section{Andreas Fejes ${ }^{1}$}

Andreas Fejes

andreas.fejes@liu.se

1 Linköping University, Linköping, Sweden 